\title{
Whole Bone Marrow
}

National Cancer Institute

\section{Source}

National Cancer Institute. Whole Bone Marrow. NCI Thesaurus. Code C84513.

Bone marrow sample containing a mixture of different types of stem cells, including hematopoietic stem cells, mesenchymal stem cells, and multipotent progenitor cells. 